\title{
Laboratory Techniques for Determining Ploidy in Plants
}

Christopher S. Cramer $^{1}$

ADDITIONAL INDEX WORDS. pollen grains, pollen mother cells, root tip squashes, stomata size, stomata density

Summary. D etermination of ploidy is an essential plant breeding technique. Laboratory exercises for teaching students how to determine ploidy in plant tissues using various techniques are described for geranium and onion. The different methods include root tip squashes, pollen mother cell squashes, pollen grain size and germinal pore counts, stomata size and density determination, and gross morphology.

$\mathrm{T}$

he determination of ploidy level is an essential technique in plant breeding and genetics. $M$ any crops represent one species in a polyploid series; others are ploidy chimeras. Ploidy determination is used extensively on plants regenerated from tissue culture as ploidy variation is common. Chromosome loss can occur often after interspecific hybridization. The objective of this laboratory is to teach students basic techniques for determining ploidy in plants. $\mathrm{N}$ ot all of the mentioned techniques may be successful for determining plant ploidy of every crop. Therefore several techniques are presented in order to allow the student to select the technique that is most appropriate for a given species.

\section{Laboratory setup}

Plant material. Geranium (Pelargonium xhortorum Bailey) will be used for pollen mother cell squashes, pollen grain size and germinal pore counts, stomata size and density and macroscopic morphological comparisons. O nion (Allium cepa L.) will be used for root tip squashes. Both diploid and tetraploid forms of geranium can be easily purchased or grown. D iploid geraniums are sometimes referred to as seedling geraniums and are sold as bedding plants. Tetraploid geraniums are propagated primarily by cuttings and are often sold as potted plants. M acroscopic morphological differences between the two ploidy forms make them easily distinguished. Diploid and tetraploid plants should be used when flowering in order to obtain pollen and pollen mother cells. O nions purchased from a supermarket are suitable.

Department of H orticultureand Agronomy, M SC 3Q , Box 30003, N ew M exico StateU niversity, Las C ruces, N M 88003-0003. 
They can provide large, thick roots with chromosomes that are easy to stain and to observe. The basal plates of the dormant onion bulbs should be soaked in water for several days before the laboratory to induce fresh root growth.

Other materials. For each exercise, forceps, scalpels, glass slides and cover slips, and a light microscope will be needed. An ocular micrometer, that is mounted on the microscope, is needed for stomata and pollen grain measurements. The stains required for the various experiments include cotton blue, acetoorcein and acetocarmine ( $D$ arlington and LaCour, 1976; Sharma and Sharma, 1980). Each stain can be purchased from most chemical companies. Both carmine and orcein must be dissolved in hot, glacial acetic acid in order to obtain an aqueous solution (D arlington and L aC our, 1976; Sharma and Sharma, 1980). Both of the chromosome experiments will require the use of an alcohol lamp. Additional itemsinclude a metric ruler, $1 \mathrm{~N}$ hydrochloric acid $(\mathrm{HCl})$, clear fingernail polish, and a ceramic crucible.

\section{Laboratory period}

The exercises in this laboratory are organized sequentially from macroscopic to microscopic ploidy assessment.

Morphology. Students should compare diploid and tetraploid plantsfor morphological differences. D iploid and tetraploid geraniums exhibit morphological differences in leaf size, leaf thickness, stem thickness, petal size, and growth rate (C ramer, 1991). Petals and leaves of tetraploid plants tend to be larger than those of diploid plants. In addition, leaves and stems of tetraploid plants tend to be thicker than those of diploid plants. Students should take at least ten independent measurements of each of these features and useat test to determine if there is a significant difference (Steel and Torrie, 1980).

SтоматA. L eaves are removed from both diploid and tetraploid plants. Clear fingernail polish is applied to the abaxial side of the leaf for a $2 \times 2 \mathrm{~cm}$ square. Allow the polish to dry. While this is drying, students can move on to another technique. After the polish hasdried, students should carefully remove the dried polish with a pair of fine-tip forceps. The polish strips are mounted on a dry microscope slide. The ocular micrometer is used to measure the largest diameter of 10 stomata at $125 \times$ (T able 1 ). In addition, students should count the number of stomata in 10 different fields of vision. They can calculate an average density for both the diploid and tetraploid plants (Table 1). Diploid plants should possess more dense, smaller diameter stomata than tetraploid plants.

Pollen Grains. M ature anthers are collected from both diploid and tetraploid plants (C ramer, 1991). The anthers are dipped in a drop of cotton blue stain on a slide. The anthers should bemacerated to release pollen grains. The anther debris should be removed and the stain with extruded pollen covered with a cover slip. After $15 \mathrm{~min}$, the slide is viewed under a light microscope at $125 \times$ and the pollen diameter of 10 pollen grains is measured using an ocular micrometer (Table $1)$. Tetraploid plants typically have larger pollen grains than diploid plants (Cramer, 1991; Philippi, 1961). Students should also count thenumber of germinal poresper grain for 10 pollen grains from both diploid and tetraploid plants (Table 1 ). Pollen grains from tetraploid plantsshould have more pores than thosefrom diploid plants (C ramer, 1991; Philippi, 1961).

Pollen mother cells. Flower buds are removed from both diploid and tetraploid plants. A range of buds with different levels of development should be collected. The range should be from small green to enlarged and slightly colored buds. From the range of bud development stages, students should be able to determine which stage is optimum for

Table 1. Sample stomata and pollen size counts, stomata density determinations, and germinal pore counts for diploid and tetraploid geranium plants.

\begin{tabular}{|c|c|c|}
\hline Ploidy & Counts & Mean \\
\hline \multicolumn{3}{|c|}{ Stomata size ( $\mu \mathrm{M})$} \\
\hline Diploid & 2.34. 2.40, 2.46, 2.60, 2.59, 2.53, 2.47, 2.32, 2.51, 2.42 & 2.46 \\
\hline Tetraploid & $\begin{array}{c}3.74,3.84,2.91,3.42,3.07,3.26,3.46,3.31,3.33,3.21 \\
\text { Stomata density (stomates/ } \text { mm}^{2} \text { ) }\end{array}$ & 3.36 \\
\hline Diploid & $29,29,27,34,31,32,27,28,32,31$ & 30.0 \\
\hline \multicolumn{3}{|c|}{ Pollen size $(\mu \mathrm{M})$} \\
\hline Diploid & $4.45,4.80,4.22,4.80,4.67,4.61,3.65,4.26,4.10,4.51$ & 4.41 \\
\hline Tetraploid & $\begin{array}{c}6.34,5.76,6.21,6.27,5.98,6.37,5.12,5.12,5.86,5.92 \\
\text { G erminal pores (no./ grain) }\end{array}$ & 5.90 \\
\hline Diploid & $2,3,2,2,3,3,1,2,2,1$ & 2.1 \\
\hline Tetraploid & $4,4,3,4,5,4,3,3,5,3$ & 3.8 \\
\hline
\end{tabular}


observation of meiosisin pollen mother cells. The flower buds should be cut with a scal pel and the anthers removed with forcepsfrom the bud. The anther is placed on a glass slide with a drop of acetocarmine stain. The anther is cut at one end with a scalpel. The uncut end of the anther should be pressed to squeeze pollen mother cells out of the anther through the cut end. The anther debris should be removed from the slide and a glass cover slip placed over the drop. The slide should be heated but not boiled by passing the slide through the flame of an alcohol lamp several times. This heating will help stain the chromosomes darker. The slide should be viewed under a light microscope at $1250 \times$ and the number of chromo somescounted from fivecells of both diploid and tetraploid plants. From those cells, students should estimatethechromosomenumber of diploid $(2 n=2 x=18)$ and tetraploid $(2 n=4 x=36)$ geraniums. Students should also be able to observe chromosomes in the different stages of meiosis. If students are unable to observe chromosomes, the incorrect stage of bud development was chosen and another bud should be selected.

Root TIPs. Small root tips $(\approx 5 \mathrm{~mm}$ in size) from actively growing rootsare cut from the onion bulb (Sundberg, 1981) and placed in a crucible containing a 9:1 solution of acetoorcein and $1 \mathrm{~N}$ hydrochloric acid. The crucible is heated over an alcohol lamp four timesfor 10 seach time. R oot tips are removed with forceps and placed on a glass slide. A drop of acetoorcein stain is placed over the root tip. A cover slip is placed over the root tip and gentle pressure is applied to the cover slip with a pencil eraser to smear the root tip. Cells will separate from each other and spread out in a single layer. The root tip smear technique may take some practice before a single layer of cellsisobtained. Chromosomesin cells undergoing mitosis can be observed under themicroscope. Studentsshould count the number of chromosomes observed in five cells at metaphase to determine the chromosome number of onion. I n addition, students should be able to observe the different stages of mitosis. The visibility of chromosomes will be related to the quality of the smearing and the degree of staining. The fixation and staining technique mentioned here isfast, relatively simple and quite effective. 0 ther techniquessuch asFeulgen or $\mathrm{G}$ iemsastain may give better chromosome definition; however, most of these techniques require additional fixation and morepreparation time ( $D$ arlington and LaC our, 1976; Sharma and Sharma, 1980). Thebenefit of this procedure is for students to be able to isolate and stain somatic chromosomes in order to count chromosome number. Students should understand that the size of onion chromosomes is much larger than most plant chromosomes. The same techniques may not provide sufficient distinction of chromosomes in many species.

\section{Followup}

Instructors should request alaboratory report that summarizes the resultsfrom the experiments. From these experiments, students should be able to determine the ploidy level of a plant at its three histogen layers. The stomata size and density experiments allow students to determine the ploidy of the $L-I$ histogen layer, while the pollen grain experiments determine the ploidy of the L-II histogen layer (Cramer, 1991). Root tips are commonly associated with the L-III histogen layer.

The time required to set up the laboratory is 30 to 60 min granted that microscopes and stains are available. Additional time should be allowed if stainsneed to be made. The laboratory was designed to run from 2 to $3 \mathrm{~h}$. Some procedures may need to be repeated before the desired results are obtained. U sing thesetechniques, students should be able to determine the ploidy of most plants. Advanced techniques, such as flow cytometry (Faure and $\mathrm{N}$ ougarede, 1993; $\mathrm{M}$ ichaelson et al., 1991; O rmerod, 1994; Shapiro, 1995; Watson, 1991), or microspectrophotometry (Faureand N ougarede, 1993; M ichaelson et al., 1991) require expensive equipment but may be necessary or efficient if many samplesneed to be processed. Partec (Partec G mbH , $M$ ünster, Germany) sells an instrument called aPloidy Analyzer for automatic ploidy determination in plants.

\section{Literature cited}

Cramer, C.S. 1991. H ybridization between diploid and tetraploid Pelargonium xhortorum Bailey. U ndergraduate honors thesis, Pa. State U niv., U niversity Park.

D arlington, C.D . and L.F. L aC our. 1976. The handling of chromosomes. 6th ed. Wiley, N ew York.

Faure, O and A. N ougarede. 1993. N uclear D N A content of somatic and zygotic embryos of Vitis vinifera cv. G renche noir at the torpedo stage. Flow cytometry and in situ DNA microspectrophotometry. Protoplasma 176:145-150.

M ichaelson, M.J., H .J. Price, J.R. Ellison, and J.S. Johnston. 1991. Comparison of plant D N A contents determined by Feulgen microspectro photometry and laser flow cytometry. Amer. J. Bot. 78:183-188.

O rmerod, M.G. 1994. Flow cytometry: a practical approach. IRL Press, 0 xford.

Philippi, G. 1961. U tersuchungen uber die fertilitatsverhaltnisse einiger kulturformen von Pelargonium zonale. $Z$. Pflanzenzuchtung 44:380-402.

Shapiro, H.M. 1995. Practical flow cytometry. 3rd ed. Wiley-Liss, N ew York.

Sharma, A.K. and A. Sharma. 1980. Chromosome techniques. Theory and practice. 3rd ed. Butterworths, London.

Steel, R.G.D . and J.H . T orrie. 1980. Principles and procedures of statistics. A biometrical approach. 2nd ed. M cG raw-H ill, $\mathrm{N}$ ew York.

Sundberg, M.D. 1981. M aking the most of onion root tip mitosis. Amer. Biol. Teacher 43:386-388.

Watson, J.V. 1991. Introduction to flow cytometry. Cambridge U niv. Press, Cambridge. 